\title{
Adversity Quotient of NEUST-SIC CoEd Faculty
}

\author{
Maricar H. Sison ${ }^{1}$, Junil A. Constantino², Eloisa C. Gabriel ${ }^{3}$, Ma. Teresita C. \\ $\mathrm{Vega}^{4}$
}

Nueva Ecija University of Science and Technology, Philippines

Received: 06 Sept 2020; Received in revised form: 12 Nov 2020; Accepted: 24 Nov 2020; Available online: 07 Dec 2020

C2020 The Author(s). Published by Infogain Publication. This is an open access article under the CC BY license

(https://creativecommons.org/licenses/by/4.0/).

\begin{abstract}
The study aims to determine the Adversity Quotient of Faculty Members of the College of Education of Nueva Ecija University of Science and Technology San Isidro Campus. The descriptive method of research was utilized using the Adversity Response Profile (ARP) Quick Take. The Percentage, Frequency, and Mean were used for the respondents' profile, academic rank, and monthly salary. Most of the respondents are between 32-38 years old, females, and already married. All of the participants have a Master's Degree, wherein five of them are Doctorate holders. The majority of the respondents have6-10 years of teaching experienceand serving as Instructor I-III. In terms of control, reach, and endurance, the $A Q$ of the majority of the faculty members is average, while in terms of ownership, it is below average. Lastly, majority of the respondents got an average level inthe over-all Adversity Quotient.
\end{abstract}

Keywords-Adversity Quotient, College of Education, Faculty, NEUST-SIC, Adversity Response Profile Quick Take.

\section{INTRODUCTION}

In the study of human behavior, people are familiar with the emotional quotient, but very few are aware of one's adversity quotient. Stolz (1997) said that Adversity Quotient is the most widely used way of measuring and strengthening human resilience. As many people from all walks of life encounter adversity, the way they face challenges determines their success and relationship with others. As Stolz (1997) further suggested, AQ is about how one responds to life, especially the tough times many people encounter every day. Challenges and conflicts in one's life significantly affect their jobs resulting in failure and struggles. Teachers at the forefront of students' learning must and should possess a high level of adversity quotient, requiring metacognitive skills in teaching. (A. Constantino et al., 2020)

Adversity Quotient is made up of four dimensions, namely, Control, Origin and Ownership, Reach, and Endurance. In a study by Titus Ng (2013), he emphasized that "Control" focuses on dealing with the adversities instead of focusing and complaining about the issues beyond control. It can maintain a can-do attitude even when the challenges are overwhelming and seek support from others when handling problems or challenges beyond control. There are individuals who respond to adversities ISSN: 2456-7620

https://dx.doi.org/10.22161/ijels.56.33 as temporary have optimistic views. As a result, they tend to enjoy life's benefits. Origin and Ownership deals with taking responsibility for any mistakes made, taking ownership in resolving problems

Even if they did not cause them, they clearly and objectively evaluated who caused the problems. According to Stoltz (1997), as cited by Santos (2012), the domain Origin and ownership ask two questions: Who or what was the origin of adversity? And to what degree do I own the outcomes of the adversity? If the origin's level is low, there is a possibility of blaming oneself for the adversities he/she is facing. Whereas, an individual with high AQ levels in this domain tends to consider other factors as sources of adversities. In short, origin and ownership speak about accountability. The third domain is Reach, and this dimension asks the question: "How far will the adversity reach into other areas of my life? (Santos, 2012; Stoltz, 1997). A low level in this domain will be most likely that adversity may affect other areas of one's life and may probably make it a big deal to the point of catastrophizing an unfortunate event.

Further, in bleak situations, succumbing to adversities may turn disappointment into a cataclysmic event. On the other hand, a high level may indicate a box-like attitude of protecting other life areas from the current adversity one is 
facing. Lastly, Endurance deals with being optimistic and may view success as enduring, if not permanent, during adversity is somewhat temporary. (Santos 2012) According toNg, T. (2013), Endurance is about exhibiting tenacity and perseverance even when the situation is uncertain or cloudy while at the same time remaining hopeful that the adversities will pass eventually.

This study was conducted to determine the Adversity Quotient of the Faculty of Nueva Ecija University of Science and Technology (NEUST-SIC) San Isidro Campus, College of Education.

Specifically, it seeks to provide significant answers to the following objectives:

1. To determine and describe the respondent's profile in terms of:
a. age
b. sex
c. civil status
d. educational attainment
e. years of service
f. academic rank
g. Monthly Salary

2. To identify the respondent's Adversity Quotient in terms of:
a. Control
b. Origin/Ownership
c. Reach
d. Endurance
e. Overall Adversity Quotient

\section{METHODOLOGY}

In determining the Adversity Quotient of the respondents, the descriptive method of research wasapplied. The descriptive method describes certain phenomena and provides an accurate description of a situation or an association between variables. One can then make statements about a particular group or population (Tejero, 2011).The study respondents were the sixteen faculty members from the College of Education, Nueva Ecija University of Science and technology, San Isidro Campus. The researchers used a survey-questionnaire as the instrument in gathering data.These were the Adversity Response Profile (ARP) Quick Take(1997) and the demographic Profile Questionnaire. The researchers asked the Campus Director to conduct the study and use the faculty members as the participants. FrequenciesPercentage was used to determine the respondents' profile, including their Age, Sex, Civil Status, Educational Attainment, Years of Service, Academic Rank, Monthly Salary, and Adversity Quotient. Qualitative analysis and descriptive statistics were utilized to describe and determine the teacher's Adversity Quotient (AQ). Mean Scores were computed perCO $\mathrm{C}_{2} \mathrm{RE}$ dimension (control, origin \& ownership, reach, and endurance) of AQ. To arrive at the teacher's AQ, the average or mean score per $\mathrm{CO}_{2} \mathrm{RE}$ dimension was added together.

Table 1. Range of Scores and Equivalent Interpretation for $A Q$

\section{Score Range Equivalent}

176-200 High

158-175 Above Average

136-157 Average

119-135 Below Average

40-118 Low

Table 2. $\mathrm{AQCO}_{2} \mathrm{RE}$ dimension Score Range and Equivalent

\begin{tabular}{|c|c|c|c|c|}
\hline High & bove & $\begin{array}{l}\text { Average } \\
\text { Average }\end{array}$ & Below & $\begin{array}{l}\text { Low } \\
\qquad \text { Average }\end{array}$ \\
\hline $\begin{array}{l}\text { Control } \\
0-29\end{array}$ & $48-50$ & $43-47$ & $36-42$ & $30-35$ \\
\hline $\begin{array}{l}\text { Origin /Ow1 } \\
10-30\end{array}$ & ership & 50 & 4941-46 & $31-40$ \\
\hline $\begin{array}{l}\text { Reach } \\
10-24\end{array}$ & $43-50$ & $38-42$ & $30-37$ & $25-29$ \\
\hline $\begin{array}{l}\text { Endurance } \\
10-25\end{array}$ & $44-50$ & $39-43$ & $32-38$ & $26-31$ \\
\hline
\end{tabular}




\section{RESULTS AND DISCUSSIONS}

\section{Part I. Profile of the Respondents}

Table 3. Age Distribution of Respondents

\begin{tabular}{|c|c|c|}
\hline Age & Frequency & Percentage \\
\hline 24 below & & 0 \\
\hline 25-31 years old & 4 & $25 \%$ \\
\hline $32-38$ years old & 5 & $31.25 \%$ \\
\hline $39-45$ years old & 2 & $12.5 \%$ \\
\hline $46-52$ years old & 2 & $12.5 \%$ \\
\hline 53-59 years old & 3 & $18.75 \%$ \\
\hline $60-65$ years old & 0 & 0 \\
\hline Total & 16 & $100 \%$ \\
\hline
\end{tabular}

Table 3 presents the demographic profile of the respondents in terms of age. Out of 16 respondents, five or $31.25 \%$ are $32-38$ years old, four or $25 \%$ are $25-31$ years old, three or $18.75 \%$ are $46-52$ years old, 2 or $12.2 \%$ are $39-45$ years, 2 or $12.5 \%$ are $46-52$ years old. This implies thatthe most significant number of respondents are 32-38 years old, while the least is below 24 years old and above 60 years old. This implies that most of the respondents are still in their prime years of becoming a teacher. They also possessed the energy of handling adversity in their respective professional domain. However, it is also believed that the more one gets older, the more that one becomes more mature and responsible for what one does.

Table 4. Sex Distribution of Respondents

\begin{tabular}{lcl}
\hline Sex & Frequency & Percentage \\
\hline Male & 7 & $43.75 \%$ \\
Female & 9 & $56.25 \%$ \\
\hline Total & 16 & 100
\end{tabular}

Table 4 presents the gender distribution of the respondents. It shows that out of 16 faculty members, $56.25 \%$ or nine (9)of the respondents were female.Studies suggested that various genders have different levels of capacities on how to respond to adversity. When encountering adversity, females have the tendency to ISSN: 2456-7620 blame themselves, while males tends focus and concentrate on the outcome of adversity. (Chao-Ying Shen, 2014; Stoltz, 2002)

Table 5. Civil Status of Respondents

\begin{tabular}{lcc}
\hline Civil Status & Frequency & Percentage \\
\hline \multirow{2}{*}{ Single } & 7 & $43.75 \%$ \\
Married & 9 & $56.25 \%$ \\
Legally Separated & 0 & 0 \\
Widow & 0 & 0 \\
$\quad$ & & \\
\multicolumn{1}{c}{ Total } & 16 & 100 \\
\hline
\end{tabular}

Table 5 presents the civil status record of the respondents. Seven or $43.75 \%$ are single, and nine or $56.25 \%$ of the respondents are married. Having a partner to handle adversities may be beneficial. But being single, married, legally separated, or widowhas nothing to do with the approach in overcoming adversity. In short, civil status is not related with any circumstances reaching into other areas of life. (Kumar, 2018)

Table 6. Educational Attainment of the Respondents

Educational Frequency Percentage
Attainment

$\begin{array}{lll}\text { Bachelor's Degree } & 0 & 0 \\ \text { Master's Degree } & 11 & 68.75 \% \\ \text { Doctorate Degree } & 5 & 31.75 \%\end{array}$

$\begin{array}{lll}\text { Total } & 16 & 100\end{array}$

Table 6 shows that 11 or $68.75 \%$ of the respondents are Master's degree holders, and 5 or $31.75 \%$ are doctorate holders. Italso shows that $100 \%$ of the respondents are all Master's degree holders, and 5 or $31.75 \%$ had pursued a higher degree after their Master's degree. The finding implies that all the respondents are more than knowledgeable about their current profession. They are also competent intellectually and well-deserving to teach in a higher-level institution such as NEUST-SIC. A master's degree is the minimum standard requirement 
for a permanent position in any state university in the Philippines.

Table 7. Years in Service of the Respondents

\begin{tabular}{|c|c|c|}
\hline $\begin{array}{l}\text { Years in } \\
\text { Service }\end{array}$ & Frequency & Percentage \\
\hline 01-05 & 5 & 31.25 \\
\hline $06-10$ & 5 & 31.25 \\
\hline $11-15$ & 1 & 6.25 \\
\hline $16-20$ & 1 & 6.25 \\
\hline $21-25$ & 1 & 6.25 \\
\hline $26-30$ & 2 & 12.5 \\
\hline 31 years and above & 1 & 6.25 \\
\hline Total & 16 & 100 \\
\hline
\end{tabular}

Table 7 reveals that 5 or $31.25 \%$ of the respondents have 1-5 years of teaching experience tied with 6-10 years of teaching experience. It also shows that the majority of the respondents have ten years and below teaching experience. Most of the faculty members of the College of Education in NEUST-SIC are relatively new to the profession. We may say that the longer a faculty member stays in the profession, the more adept he/she is taking care of adversities related to their job.

Table 8. Academic Rank of the Respondents

\begin{tabular}{lll}
\hline Academic Rank & Frequency & Percentage \\
\hline Instructor I-III & 8 & $50 \%$ \\
Assistant Professor I-IV & 3 & $18.75 \%$ \\
Associate Professor I-V & 3 & $18.75 \%$ \\
Professor I-VI & 2 & $12.5 \%$ \\
& & \\
Total & 16 & 100
\end{tabular}

Table 8 presents the academic rank of the respondents. The data reveals that eight or $50 \%$ are instructors, while the remaining $50 \%$ are distributed to higher academic ranks. Three or $18.75 \%$ are assistant professors, three or $18.75 \%$ are associate professors, and two or $12.5 \%$ are professors. According to Bautista (2015), faculty members who have higher academic ranks, such as assistant and associate professors, have become wellversed in strategies and ways to cope with various teaching ISSN: 2456-7620 complexities. Meaning to say, their ability to be promoted to a higher position reflects their behavior in responding to the challenges they have encountered before achieving such a position or rank. Bautista (2015) also added that these people had put themselves in higher positions through hard work and perseverance.

Table 9. Frequency Distribution of the Respondent's Adversity Quotient as to Control

\begin{tabular}{lcc}
\hline Adversity Level & $\begin{array}{c}\text { Control } \\
\text { Frequency }\end{array}$ & Percentage \\
\hline High & 1 & $6.25 \%$ \\
Above Average & 3 & $18.75 \%$ \\
Average & 7 & $43.75 \%$ \\
Below Average & 4 & $25 \%$ \\
Low & 1 & $6.25 \%$ \\
\hline
\end{tabular}

Table 9 revealed that in terms of control, majority of the respondents has an average level of adversity quotient, with $43.75 \%$. It indicates that most of the respondents may respond to adverse events at least partially within their control, depending on the event's magnitude. At this level, one can maintain an optimistic viewer perception of the situation even if the challenges seem too big to conquer. This study also implies thatan individual with more grip on the case or more control, the more likely they are inclined to do actions that may bring positive results.

Table 10. Frequency Distribution of the Respondent's Adversity Quotient as to Origin and Ownership

\begin{tabular}{lll}
\hline & Ownership & \\
Adversity Level & Frequency & Percentage \\
\hline High & 2 & $12.5 \%$ \\
Above Average & 0 & 0 \\
Average & 3 & $18.75 \%$ \\
Below Average & 8 & $50 \%$ \\
Low & 3 & $18.75 \%$ \\
\hline
\end{tabular}

Table 10 reveals that in terms of origin/ownership, the majority of the participants have a below-average level of adversity is $50 \%$. It can also be seen that no one registered an above-average level of adversity, but 2 participants registered a high level of adversity quotient in terms of origin/ownership. It could be said that the lower one's adversity quotient on this domain, the more one may view problems as his fault even if they did not cause them and fortunate circumstances as a 
product of good luck because of other forces.( $\mathrm{Ng}, \mathrm{T} .2013)$ The finding implies that most of the respondents may doubt themselves, which may eventually lead to withdrawal on significant hurdles.(Bantang et al., 2013)

Table 11. Frequency Distribution of the Respondent's Adversity Quotient as to Reach

\begin{tabular}{lcc}
\hline \multicolumn{1}{c}{ Adversity Level } & $\begin{array}{c}\text { Reach } \\
\text { Frequency }\end{array}$ & Percentage \\
\hline High & 2 & $12.5 \%$ \\
Above Average & 3 & $18.75 \%$ \\
Average & 8 & $50 \%$ \\
Below Average & 0 & 0 \\
Low & 3 & $18.75 \%$ \\
\hline
\end{tabular}

Regarding reach, the respondents have also average level of adversity quotient with $50 \%$ while 18.75 respondents have a low level of adversity quotient. This finding reveals that most of them have a moderate capacity to give full attention and energy to other areas not affected by the adversities. Persons with an average level of adversity quotient toreach may respond to adversities as pointing to a particular situation that may not necessarily affect other areas of their life. Although the result is average, there is still a tendency for the respondents to catastrophize an event, thus making bad events more farreaching, when it is not that bad in reality.

Table 12. Frequency Distribution of the Respondent's Adversity Quotient as to Endurance

\begin{tabular}{lcc}
\hline \multicolumn{1}{c}{ Adversity Level } & $\begin{array}{c}\text { Endurance } \\
\text { Frequency }\end{array}$ & Percentage \\
\hline High & 4 & $25 \%$ \\
Above Average & 4 & $25 \%$ \\
Average & 6 & $37.5 \%$ \\
Below Average & 0 & 0 \\
Low & 2 & $12.5 \%$ \\
\hline
\end{tabular}

The table shows that $37.5 \%$ of the respondents have an average level of adversity in terms of endurance, and no one is registered below-average level. This suggests that most participants have a moderate capacity to exhibit tenacity and perseverance, even when the situation is uncertain. They remain hopeful that the adversities will eventually pass away. It can also be noted from the table that a quarter of the respondents registered "Above Average" and "High" in terms of endurance. This indicates ISSN: 2456-7620 that $50 \%$ of the NEUST-SIC College of Education faculty members may perceive adversity as temporary.

Table 13. Overall Frequency Distribution of the Respondent's Adversity Quotient

\begin{tabular}{lcc}
\hline \multicolumn{1}{c}{ Adversity Level } & $\begin{array}{c}\text { Overall } \\
\text { Frequency }\end{array}$ & Percentage \\
\hline High & 2 & $12.5 \%$ \\
Above Average & 3 & $18.75 \%$ \\
Average & 7 & $43.75 \%$ \\
Below Average & 2 & $12.5 \%$ \\
Low & 2 & $12.5 \%$ \\
\hline
\end{tabular}

Most importantly, as can be gleaned from Table 13, the participants' over-all adversity quotient falls on the average range. This implies that most faculty members can control and deal with adverse situations they encounter in their lives. In responding to adversity, the respondents are considered optimists. They see adversity and problems as challenges, see problems as temporary, limited, and external to themselves, do not internalize issues, and have a 'This too shall pass' philosophy.' (Ferrer, 2009; Bautista, et.al,2012) In terms of the over-all Adversity Quotient Level, the faculty of the College of Education NEUST-SIC belongs to an average range. This finding implies that the faculty member s possessed a balanced outlook in life in perceiving adversities.

\section{CONCLUSIONS}

1. Majority of the respondents were married, female, Master's degree holders, and have served the university as an instructor for five to ten years.

2. In terms of Control, Reach, and Endurance, the faculty of education of NEUST San Isidro Campus is within the average range. However, in terms of ownership, they are below average.

3. The faculty of College of Education of NEUST San Isidro Campus overall have an average Adversity Quotient level.

\section{RECOMMENDATIONS}

1. It is recommended that the majority of the facultyof education pursue doctorate degrees to gain more skills in handling adversities.

2. An intervention programin the form ofseminars and training is also recommended for faculty members to make 
them more resilient and competent university members.

3. Future researchers may broaden the scope and apply this researchto the other members of the faculty of other colleges in NEUST.

\section{REFERENCES}

[1] Adiong, G.\& Angeles, T.G. (2019). Emotional Intelligence, Adversity Quotient ${ }^{\circledR}$, and Work Performance among selected Mental Health Service Providers. Retrieved fromhttps://www.peaklearning.com/wpcontent/uploads/2020/06/PEAK_GRI_AdiongAngeles May-2019.pdf

[2] A. Constantino, J., H. Sison, M., \& S. De Guzman, P. (2020). Metacognitive Awareness and General Average Grade of 2nd Year BEED and BSE Students of NEUSTSIC.International Journal of English Literature and Social Sciences (IJELS), 5(2). Retrieved from http://journalrepository.com/index.php/ijels/article/view/17 29

[3] Bantang et al., 2013. The Relationship of Personal Characteristics and Job Satisfaction to Adversity Quotient of Police Officers in Manila Police District. Retrieved from https://www.peaklearning.com/wpcontent/uploads/2019/05/PEAK GRI caguingin.pdf

[4] Bautista, MJ. (, 2015). Adversity Quotient and Teaching Performance of Faculty Members. International Journal of Scientific and Research Publications, 5(3).Retrieved from http://www.ijsrp.org/research-paper-0315/ijsrp-p3984.pdf

[5] Bautista,Reizel Lois V., Pascua, Marielle Galilea, D. Tiu, Joji V., and Vela,Catherine D.O (2016). Adversity Quotient ${ }^{\circledR}$ and Leadership Style among student leaders in Bulacan State University. .Retrieved from https://www.peaklearning.com/wpcontent/uploads/2019/05/PEAK_GRI_Bautista_Pascua_Tiu Vela.pdf

[6] Cabual, R. 2013. Adversity Quotient and the Performance Levels of Deans of Colleges of Education in Selected Private Schools in Region III; Their Implications to Educational Leadership. College of the Immaculate Conception.

[7] Canivel, L. (2010). Principals' Adversity Quotient: Styles, Performance, and Practices. Retrieved from https://www.peaklearning.com/wpcontent/uploads/2019/05/PEAK_GRI_canivel.pdf

[8] Daloos, Monica Joy O., 2015.Emotional Intelligence and Adversity Quotient of Selected helping Professionals. Retrieved from:Peak Learning.com/wp.content/uploads/2019/PEAK_GRI_daloos. pdf

[9] Huijuan, Zhou. (, 2009). The Adversity Quotient and Academic Performance among College Students at St. Joseph's College, Quezon City.Retrieved from: https://www.peaklearning.com/wpcontent/uploads/2019/05/PEAK_GRI_huijuan.pdf

[10] Kumar R (2016) The Relationship of Personal
Characteristics and Job Satisfaction to Adversity Quotient of Police Officers in Shimla District of Himachal Pradesh. Int J Econ Manag Sci 5: 331. doi:10.4172/21626359.1000331

[11] Medallo, E. \& Constantino, J. (2020). Extent and barriers of Collaboration among Administrators in Teachers' Professional Development Program. Journal of Humanities and Education Development (JHED) ISSN: 2581-8651

[12] Ng, T. (2013). Organizational Resilience and Adversity Quotient of Singapore Companies. DOI: 10.7763/IPEDR. 2013. V65. 17 Retrieved from http://www.ipedr.com/vol65/017-ICEBI2013-Y10022.pdf

[13] Rafols, J. (2013). Profile, Adversity Quotient ${ }^{\circledR}$, and Multifactor Leadership Characteristics of Student Affairs and Services Administrators: towards a Leadership Management Training Design. Retrieved from https://www.peaklearning.com/wpcontent/uploads/2019/05/PEAK_GRI_Rafols.pdf

[14] Santos, M.C., 2012. Assessing the Effectiveness of the Adapted Adversity Quotient Program in a Special Education School. Retrieved from https://www.researchgate.net/publication/265846946_ASS ESSING_THE_EFFECTIVENESS_OF_THE_ADAPTED _ADVERSITY_QUOTIENT_PROGRAM_IN_A_SPECIA L_EDUCATION_SCHOOL

[15] Stoltz, P.(1997). Adversity quotient: Turning obstacles into opportunities. USA, John Wiley \& Sons, Inc

[16] Stoltz, P. G. (2002). Adversity quotient at work: Makeeveryday challenges the key to your success; Putting the principles of AQ into action. New York: Morrow.

[17] Teero, Erlinda G., 2011.A Simplified ApproachtoThesis and Dissertation Writing. National Book Store, Inc. 36 pp

[18] 18.An Emerging Determinant of Success and Superior Performance. Retrieved from: http://stitchestm.blogspot.com/2007/09/adversity-quotientaq-emerging.html

[19] Chao-Ying Shen, 2014. The Relative Study of Gender Roles, and Job Stress and Adversity Quotient. The Journal of Global Business Management. Volume 10 Number 1. Retrieved from http://www.jgbm.org/page/3\%20Shen\%20Chao-Ying.pdf 